\title{
Analysis of Organizational Commitment, Motivation, Work Ability, and the Working Environment to Employees Performance in the Covid-19 Era
}

\author{
Sri Langgeng Ratnasari ${ }^{1 *}$, Herni Widiyah Nasrul$^{2}$, Ishan Nurdin ${ }^{3}$, Yuli Susilowati ${ }^{4}$, \\ Ervin Nora Susanti ${ }^{5}$
}

1, 2, 3, 4, 5 Universitas Riau Kepulauan, Batam, Indonesia

*Corresponding auhthor. Email: sarisucahyo@yahoo.com

\begin{abstract}
This study is to analyze the influence of: commitment of organizational on employee performance, motivation of work on employee performance, ability of work on employee performance, environment of work on employee performance, and commitment of organizational, motivation of work, ability of work, and environment of work on employee performance. This type of research includes quantitative research. The population of research is PT. AEI employee of permanent as many as 154. The technique of the sampling used samples of saturated, respondents of this research were 154 respondents. Data obtained through a questionnaire. The data analysis technique used SPSS. The research of the results are: commitment of organizational has a significant influence on performance of employee, motivation of work has a significant influence on performance of employee, ability of work has a significant influence on performance of employee, and the environment of work has a significant influence on performance of employee. The results of the research simultaneously show that all of variables have significant influence on employee performance.
\end{abstract}

Keywords: Performance, Organizational Commitment, Motivation, Ability, Environment.

\section{INTRODUCTION}

Resource of human one of major factor on the company, therefore the organization must maintain organizational commitment properly so that employees make maximum contributions to the organization. Organizational commitment is a process that takes place spontaneously and naturally that grows through individual association with the organization [1] Motivation are very important, needed for all company because motivation can to be change, enhance more on employee performance [2].

According to [3] work ability is one of the elements of maturity related to skills, knowledge that can be get from education, training, and experience. Ability related to the physical, mental abilities an employee doing the job and not what he wants to do.

According to [4], the work environment is a very important component when employees carry out work activities. Attention to a good work environment can provide motivation to work to maximum result.

According to [5], performance is the result of employee as a total during a certain period in carrying out the job, like work standard, target or criteria that have been set in advance and have been mutually agreed. Success of an organization with a variety of performance depends on the performance of the participants in the organization concerned.

Before the research was conducted, a survey was conducted to determine the problems in the research area. The survey results show that organizational commitment is still weak, employee work motivation is still not optimal, employee work ability is still not optimal, the work environment is still not comfortable, and performance of employee is not optimal.

Based on the background of the problems that have been stated, the research problem are: Does organizational commitment affect performance of 
employee? Does work motivation affect performance of employee? Does work ability affect performance of employee? Does the work environment affect performance of employee? Do all of variables are affect performance of employee?

\subsection{Literature Review}

\subsubsection{Employee performance}

According to [6], performance of employee is result of job in quantity and quality achieved to worker in completed a task in responsibilities assigned.

\subsubsection{Organizational Commitment}

Managing human resources in an organization needs to be considered the commitment of its employees. High employee commitment will greatly affect the achievement of organizational goals. Organizations will find it easier to achieve goals and objectives if employees are committed to the organization,[7].

\subsubsection{Motivation}

Motivation is concepts of psychology, that is most important to leaders who is direct subordinates to ensure objective of worthwhile [8]. To develop an organization of all employees, leaders must fully concentrate on organizational goals.

\subsubsection{Work ability}

According to [9] Ability shows an individual's capacity to realize various tasks at work. Is an assessment of what someone is doing right now.

\subsubsection{Work environment}

[10] The work environment is a condition in an organization. To develop an organization of all employees, leaders must fully concentrate on organizational goals.

\section{RESEARCH METHODS}

This type of research is quantitative research, using primary data sources, namely data sources obtained from the object of research, by means of questionnaires to respondents.

\subsection{Research Population}

The population are 154 people of permanent worker/employees of PT. Austin Engineering Indonesia.

\subsection{Research Samples}

The sample in this study were 154 people using saturated samples, the entire population was studied.

\subsection{Research Instruments}

This study uses a Likert scale using a questionnaire.

\subsection{Technique of data analysis}

Data analysis used quantitative analysis. Data analysis is an activity after the data is collected from all respondents. Data analysis techniques in quantitative research use inferential statistics.

\subsection{Regression of Multiple Linear}

Analysis of the data using regression of multiple linear. The choice of multiple linear regression analysis because this study consists of five independent variables, namely Commitment of Organizational (X1), Motivation of Work (X2), Ability of Work (X3), Environment of Work (X4) and the dependent variable: Performance of Employee (Y).

\subsection{Multiple Regression Analysis}

Result of the data, the following multiple linear regression equation is obtained: $\mathrm{Y}=-10.853+0.228 \mathrm{X} 1$ $+0.160 \mathrm{X} 2+0.346 \mathrm{X} 3+0.527 \mathrm{X} 4+\mathrm{e}$.

Multiple linear regression equation result, it can be concluded as follows: The constant coefficient is 10,853 meaning that if PT. AEI does not consider Commitment of Organizational, Motivation of Work, Ability of Work, Environment of Work means that as independent variables have no influence, the value of performance of employee results is $-10,853$.

Organizational commitment has a value of 0.228 , meaning that every time there is an increase in $\mathrm{X} 1$ of $1 \%$, then performance of employee will increase by 0.228 . Work motivation value of 0.160 means that every time there is an increase in $\mathrm{X} 2$ of $1 \%$, then the performance of employee will increase by 0.160 .

Work ability has a value of 0.346 , meaning that every time there is an increase in X3 by $1 \%$, then the performance of employee will increase by 0.346 . The work environment has a value of 0.527 , meaning that every time there is an increase in $\mathrm{X} 4$ by $1 \%$, then the performance of employee will increase by 0.527 .

\section{7. $T$ test}

The t-test in this research was carried out by compared of tcount with ttable.

If value of tcount $>$ ttable at the significance level $\alpha$ $=0.05$ from the $\mathrm{t}$ value of commitment of organizational, Motivation of work, Ability of Work, and Environment of work, meaning that the independent variable partially positive effect on the dependent variable.

If value of tcount $<$ ttable at the significance level $\alpha=$ 0.05 from the $t$ value of commitment of organizational, Motivation of work, Ability of work, and Environment of work, it means that the independent variable does not influence partially on the dependent variable. 
Based on partial test results, the following results were obtained:

Commitment of Organizational has a tcount value of $3.581>0.677$ ttable, with a significance of $0.001<0.05$, it means that Commitment of Organizational have significant influence on the employee performance.

Motivation of work has a value of tcount of 2.789> 0.777 ttable, with significance of value $0.004<0.05$, it means work motivation has a significant of influence on performance of employee.

Work ability has a value of $t_{-}$(count) of 5.816> 0.677 ttable, with a significance value of $0.000<0.05$, accepted it means work ability have significant of influence on performance of employee.

The work environment has a value of $t$ count of $7,716>0.767$ ttable, with a significance value of 0.000 $<0.05$, it means that it have significant of influence on performance of employee.

Work environment is the most dominant partially independent variable influence on performance of employee.

Results of the t test (partial test) that has been stated above, it shows that the variables of commitment of organizational, motivation of work, ability of work, and environment of work has positive of influence on performance of employee.

\subsection{Test of $F$}

Test of $\mathrm{F}$ determine of the influence of the variable of independent simultaneously on the variable of dependent. The result base on of the test of simultaneous, it shows that the value of $\mathrm{F}$ count is $87.42>2.47$ Table of $F$ significance on value of 0.000 $<0.05$. Thus it is concluded that commitment of organizational, motivation of work, ability of work, and environment of work simultaneously have a significant influence on performance of employee.

\section{DISCUSSION}

\subsection{Influence of Commitment of Organizational on Performance of Employee}

Hypothesis testing result of commitment of organizational variable resulted in a value of tcount of 3,581 greater than ttable with $\mathrm{df}=\mathrm{n}-2=96-2$ of 0.677 and a significant value of $000<0.05$, then H_01 was rejected, $H_{-} \alpha 1$ was accepted. Thus in partial test the variable commitment of organizational has a significant influence on performance of employee. This is because commitment of organizational is able to better influence performance of employee results. The results support the research results of [11], [12]

\subsection{Influence of Motivation of Work on Performance of Employee}

Hypothesis testing result of the motivation of work variable resulted in a value of tcount of 2,789 greater when compared with ttable with df $=\mathrm{n}-2=96-2$ of 0.677 and a significant value of $000<0.05$. H_02 rejected and H_a2 accepted, and Thus the partial test of motivation of work has a significant influence on performance of employee. This is because motivation is able to better influence performance of employee results. The results of this study support of [10],[13].

\subsection{Influence of Ability of work on Performance of Employee}

Hypothesis testing result for ability of work have positive significant influence on employee of performance, the tcount value is 5,816 , which is greater than the ttable of 0.677 and a significant value of 000 $<0.05$. H_03 rejected and H_ $\alpha 3$ accepted, and in a partial test, the Ability of work variable has a significant influence on performance of employee. This is due to good work abilities being able to complete tasks and responsibilities properly. Therefore, it can be concluded that good employee ability of work will have an influence on performance of employee results. The results support results of [13]).

\subsection{Influence of Environment of work on Performance of Employee}

Hypothesis testing result of the environment of work have positive significant influence on employee performance. The tcount value is 7,716 greater when compared to ttable of 0.677 and a significant value of $0.000<0.05$, then $\mathrm{H}_{-} 04$ is rejected and $\mathrm{H}_{-} \alpha 4$ is accepted, thus the partial test of the environment of work has a significant influence on performance of employee. This is because a clean and comfortable work environment will affect the performance of employees to better complete their duties and responsibilities. Therefore, it can be concluded that a clean and comfortable employee environment of work can influence performance of employee for the better. The results of this research support the results of [14], [15], [16], [17], [18], [19]

\subsection{Influence of Commitment of Organizational, Motivation of work, Ability of work, and Environment of work on Performance of Employee}

Hypothesis testing result of commitment of organizational, motivation of work, ability of work, and environment of work simultaneously have positive significant inluence on employee performance. The Fcount value of 87,420 is greater when compared to the 
Ftable value of 2.47 and significance of value of $0.000<0.05$, it means that $H_{-}(0) 5$ is rejected and $H_{-}(\alpha)$ 5 is accepted, thus the $\mathrm{F}$ test simultaneously has an influence on performance of employee. This is because commitment of organizational, motivation of work, ability of work, and environment of work can be improve performance of employee so that the goals and vision and mission of the company can be achieved and according to the company's targets. The results of this research support the research results of[20], [21],[22]

\subsection{Conclusion}

The results of the research and discussion as follows: Commitment of Organizational have significant influence on employee performance. Motivation of work has a significant influence on employee performance. Ability of work have significant influence on employee performance. Environment of work have significant influence on employee performance. Commitment of Organizational, Motivation of work, Ability of work, and Environment of Work simultaneously have significant influence on employee performance.

\section{AUTHORS' CONTRIBUTIONS}

Based on the conclusions and research results, the following suggestions can be given: The company is expected to retain employees who have a strong organizational commitment so that they can continue to improve performance can be create employees of loyal so as to maintain the performance of employees so that the goals and vision and mission of the company can be achieved. To improve performance of employee, it can be done by providing motivation of work for employees so that employees have high morale and creative work, high responsibility in completing their assigned tasks. The company is expected to maintain the work ability of employees, where so far employees have good work abilities in carrying out activities and responsibilities. Companies are expected to increase training to improve quality. The company want to create a good environment of work to enhance performance of employee, especially in terms of placing equipment that can interfere with employee activities, one of which is air pollution. Performance of employee needs to be maintained, to increase work productivity.

\section{REFERENCES}

[1] C. M. D. Ramalho Luz, S. Luiz de Paula, and L. M. B. de Oliveira, "Organizational commitment, job satisfaction and their possible influences on intent to turnover," Rev. Gestão, vol. 25, no. 1, pp. 84-101, 2018.

[2] M. S. Aarabi, I. D. Subramaniam, and A. B. A. A. B. Akeel, "Relationship between motivational factors and job performance of employees in Malaysian service industry," Asian Soc. Sci., vol. 9, no. 9, pp. 301-310,
2013.

[3] S. Ghaffari, J. Burgoyne, and M. Nazri, "The Influence of Motivation on Job Performance: A Case Study at Universiti Teknologi Malaysia," Aust. J. Basic Appl. Sci., no. March, pp. 92-99, 2017.

[4] Z. M. Elok Mahmud Putri, Vivin Maharani Ekowati , Achmad Sani Supriyanto, "THE EFFECT OF WORK ENVIRONMENT ON EMPLOYEE PERFORMANCE THROUGH WORK DISCIPLINE," Int. J. Res.

Granthhaalayah, vol. 7, no. April, 2019.

[5] N. Fogaça, M. C. B. Rego, M. C. C. Melo, L. P. Armond, and F. A. Coelho, "Job Performance Analysis: Scientific Studies in the Main Journals of Management and Psychology from 2006 to 2015," Perform. Improv. Q., vol. 30, no. 4, pp. 231-247, 2018.

[6] zuhair abbas Avinash advani, "The Impact of Transformational and Transactional Leadership Styles on Employee's Performance," Pakistan Soc. Sci. Rev., vol. 1, no. 2, pp. 119-135, 2017.

[7] H. Ahmad, K. Ahmad, and I. Ali Shah, "Relationship between Job Satisfaction, Job Performance Attitude towards Work and Organizational Commitment," Eur. J. Soc. Sci., vol. 18 , no. 2, pp. 257-267, 2010.

[8] A. Ali, M. Abrar, and J. Haider, "Impact of Motivation on the working performance of employees-A case study of Pakistan," Glob. Adv. Res. J. Manag. Bus. Stud., vol. 1, no. 4, pp. 126-133, 2012.

[9] E. A. Kadijk, S. van den Heuvel, J. F. Ybema, and F. R. M. Leijten, "The Influence of Multimorbidity on the Work Ability of Ageing Employees and the Role of Coping Style," J. Occup. Rehabil., vol. 29, no. 3, pp. 503-513, 2019.

[10] S. U. A. Syed Umair Abid, "The Impact of Rewards on Employee Motivation, the Mediating role of Office Design: Empirical Evidence from Hotel Industry of Pakistan.," IOSR J. Bus. Manag., vol. 7, no. 6, pp. 46-51, 2013.

[11] S. Biswas, "P Sychological Climate and Affective Commitment As," vol. VII, no. 2, 2011.

[12] B. M. Nwibere, "Interactive Relationship Between Job Involvement, Job Satisfaction, Organisational Citizenship Behaviour, and Organizational Commitment in Nigerian Universities," Int. J. Manag. Sustain., vol. 3, no. 6, pp. 321-340, 2014.

[13] E. S. C. Dodi Fahrurozi, Suharto, "The influence of working ability and work environment to the performance of civil servants by motivation of employees work information defense of land arrangement Indonesia,” Int. J. Multidiscip. Res. Dev. Int. J. Multidiscip. Res. Dev. Online ISSN Issue, vol. 163, no. 12, pp. 
2349-4182, 2017.

[14] K. Chandrasekar, "Workplace environment and its impact on organisational performance in public sector organisations," Int. J. Enterp. Comput. Bus. Syst., vol. 1, no. 1, pp. 1-19, 2011.

[15] N. Yusuf and S. Metiboba, "Work Environment and Job Attitude among Employees in a

Nigerian Work Organization," J. Sustain. Soc., vol. 1, no. 2, pp. 36-43, 2018.

[16] A. Bindu, "A Study on The Impact of Work Environment on Employee Performance-Ms. Bindu Anto Ollukkaran and Dr," Namex Int. J. Manag. Res., vol. 2, no. 2, pp. 71-85, 2012.

[17] A. Aisha, "Effects of Working Ability, Working Condition, Motivation and Incentive on Employees Multi-Dimensional Performance," Int. J. Innov. Manag. Technol., vol. 4, no. 6, pp. 605-609, 2013.

[18] D. Bakotić and C. Fiskovića, "Relationship between Working Conditions and Job Satisfaction : The Case of Croatian Shipbuilding Company," vol. 4, no. 2, pp. 206-213, 2013.

[19] S. O. Mokaya, J. L. Musau, J. Wagoki, and K. Karanja, "Effects of Organizational Work Conditions on Employee Job Satisfaction in the Hotel Industry in Kenya," Int. J. Arts Commer., vol. 2, no. 2, pp. 1929-7106, 2013.

[20] R. Saleem, A. Mahmood, and A. Mahmood, "Effect of Work Motivation on Job Satisfaction in Mobile Telecommunication Service Organizations of Pakistan,” Int. J. Bus. Manag., vol. 5, no. 11, pp. 213-222, 2010.

[21] khalid, "khalid," in Impacts of job satsfection on organizational commitment. Atheoratical model for academicians in HEI of developing countries like pakistan, 2013.

[22] S. L. Ratnasari, G. Sutjahjo, and Adam, "The effect of job satisfaction, organizational culture and leadership on employee performance," Ann. Trop. Med. Public Heal., vol. 23, no. 13 A, 2020. 